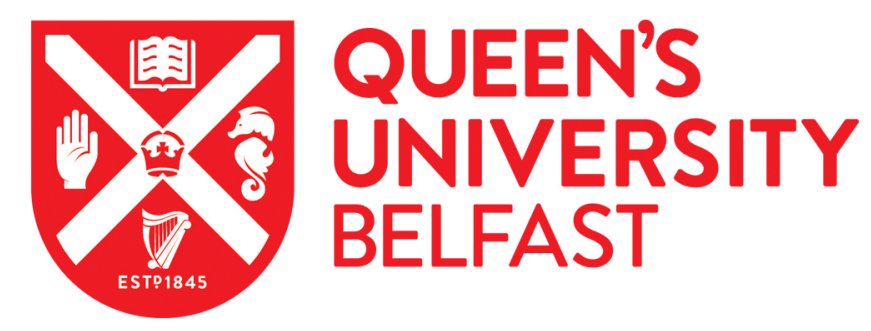

\title{
Framing Christian Eschatology through Natural Teleology? Theological Possibilities and Concerns
}

Leidenhag, M. (2019). Framing Christian Eschatology through Natural Teleology? Theological Possibilities and Concerns. Heythrop Journal . https://doi.org/10.1111/heyj.13305

Published in:

Heythrop Journal

Document Version:

Peer reviewed version

Queen's University Belfast - Research Portal:

Link to publication record in Queen's University Belfast Research Portal

Publisher rights

(c) 2019 Trustees for Roman Catholic Purposes Registered. Published by John Wiley \& Sons Ltd.

This work is made available online in accordance with the publisher's policies. Please refer to any applicable terms of use of the publisher.

\section{General rights}

Copyright for the publications made accessible via the Queen's University Belfast Research Portal is retained by the author(s) and / or other copyright owners and it is a condition of accessing these publications that users recognise and abide by the legal requirements associated with these rights.

Take down policy

The Research Portal is Queen's institutional repository that provides access to Queen's research output. Every effort has been made to ensure that content in the Research Portal does not infringe any person's rights, or applicable UK laws. If you discover content in the Research Portal that you believe breaches copyright or violates any law, please contact openaccess@qub.ac.uk. 


\section{Framing Christian Eschatology through Natural Teleology? Theological Possibilities and Concerns}

Mikael Leidenhag

New College. University of Edinburgh. Mound

Place. EH1 2LX. UK.

mleidenh@ed.ac.uk.

Christian theology typically maintains that God is transforming the universe into a New Creation. Christianity is significantly forward looking with its concern with the 'last things' and the final destinies of individual people, human history, and the cosmos as a whole. ${ }^{1}$ The history of the world is, therefore, interpreted in light of what will come. A theology of creation, given this eschatological understanding, entails a teleological view of nature moving towards a transcendent future that is revealed proleptically in Jesus Christ. In this way, evolutionary history is interpreted against the backdrop of eschatology, so that for Christianity purpose is a real feature of creation. As John Haught has suggested, creation is purposeful and teleological in that it is 'orientated towards the implementation of something intrinsically good.' ${ }^{2}$

Yet, the idea of teleology has come under attack by modern science and evolutionary biology in particular. It is argued that science with its emphasis on mechanistic explanations leaves no room for Aristotle's 'final cause' and no intrinsic goal-directedness in nature. While teleological language often shows up in biological discourse, such language is generally seen as an unwanted legacy from the Christian tradition. ${ }^{3}$ In many cases, philosophers propose solutions relating to teleonomy, which suggests that natural laws bring about only the appearance of purpose. Notable thinkers persist in claiming that purpose in nature is mere illusion. Steven Weinberg famously argued that the increase in scientific knowledge meant the rejection of purpose: 'The more the universe seems comprehensible, the more it also seems pointless. ${ }^{4}$ William Provine follows this anti-purpose materialism, saying that 'Modern science directly implies that the world is organized strictly in accordance with deterministic principles or chance. . . There are no purposive principles whatsoever in nature. ${ }^{5}$ There is neither direction nor progress within the biological world. As Stephen Jay Gould suggested, 'progress is a noxious culturally embedded, untestable, nonoperational, intractable idea that must be replaced if we wish to understand the patterns of history. ${ }^{6}$ For 
Alex Rosenberg the message of science is 'absolutely clear: no teleology, no purposes, goals, or ends.' 7

In this way, we have a clash, or at least some kind of conceptual tension, between an eschatological account of creation as progressing towards its ultimate fulfilment and a naturalistic understanding and even rejection of teleological phenomena. This paper will explore new accounts of teleology through Terrence Deacon, Stuart Kauffman, and Simon Conway Morris. They each propose a view of teleology as real, irreducible, and fully natural. In effect, these teleological accounts pave way for a post-reductionist ontology which Christian eschatology can dialogue with. This paper will explore the possibilities and concerns of articulating an eschatological account of creation through natural teleology. First, I will briefly explain the modern resistance to teleology within the biological world, and thereafter explicate Deacon's, Kauffman's, and Conway Morris's natural teleology. I will then explore the theological benefits of synthesising natural teleology with eschatology. The final section will pose some challenges for a theological accommodation of natural teleology and analyse the implications of eschatology for the issue of divine non-interventionism. My conclusion will be that although this proposed synthesis faces some theological issues, updated accounts of teleology provide conceptual and ontological resources for framing God's ongoing eschatological transformation of creation.

\section{THE MODEST RETURN OF TELEOLOGY}

Teleological notions show up in both scientific and every-day discourses. We often say that we did so-and-so because we wanted to achieve this or that; or, we $\operatorname{did} X$ for the sake of $Y{ }^{8}$ Teleology, therefore, is commonly described as 'the study of ends and goals, things whose existence or occurrence is purposive. ${ }^{9}$ A teleological explanation, then, makes reference to causes that "can only be understood in terms of the future. ${ }^{10}$ Despite being semantically prevalent, teleology (within biology) is met with scepticism and is usually accused of bringing in animism and supernaturalism through the back door. ${ }^{11}$ Because of this worry, scholars have taken on the challenge of explaining teleology through non-teleological categories.

It should be noted that the project of reducing or eliminating teleological categories is a part of a greater ambition to cleanse biological discourse from the legacy of Aristotelian philosophy. Aristotle's unapologetic account of teleology stated that actions, institutions, 
industries, arts and different artefacts exist for some purpose. ${ }^{12}$ Such purposes, for Aristotle, depend on minds and on 'agents aiming (or intending, designing, planning, etc.) for certain results. ${ }^{13}$ Teleology, so conceived, implies a rejection of the robust Cartesian split between human and non-human animals by suggesting that some animals exhibit goal-directedness. The world is full of 'purposeful striving, in which each of the four elements of the sublunary realm - earth, water, air and fire. . ' strive towards its proper actualisation. ${ }^{14}$ Consequently, an organism's intrinsic nature is 'its path toward nature', and its process of self-realization constitutes its identity. ${ }^{15}$

There is widespread hermeneutical disagreement among scholars regarding the ontological status of teleology within Aristotelian metaphysics, but it seems as if a good case can be made that teleological phenomena are understood as sui generis; neither eliminable nor reducible to more basic physical categories. That is, 'Aristotle is a nonreductive realist when it comes to teleology.' ${ }^{16}$ Sui generis teleology, however, has been vigorously resisted within modern biology, and has been viewed as an obstacle to scientific progress. As Richard Cameron points out, 'central figures in the modern scientific revolution often disparaged Aristotelian science - including its invocations of teleology - in advancing their new theories. ${ }^{17}$ Evolutionary biology, given its emphasis on causal-mechanistic explanations, is considered intrinsically post-Aristotelian. If it is possible to account for a phenomenon in a causal-mechanistic manner - i.e. by citing the relevant mechanisms that caused it - then we should in the spirit of Ockham shave away any superfluous teleological explanations. ${ }^{18}$ This is what Charles Darwin delivered in Origin; the mechanism of natural selection, which is at the centre of evolutionary thinking and the framework of Neo-Darwinism. Acknowledged by Darwin was the fact that organisms seem as if designed and that particular adaptations give the impression of being teleological or end-directed. Such end-directedness, for many pre-evolutionists, seemed to indicate the presence and activity of a sovereign God. Darwin, however, 'argued that natural selection, unaided, can do the job. ${ }^{19}$

I will now turn to some recent attempts to reintroduce natural teleology into evolutionary biology. Such updated accounts can be found in Terrence Deacon, Stuart Kauffman and Simon Conway Morris. I will, however, not provide an in depth exploration of each person's work, but rather extract their general strategy for grounding teleology within the natural order. 
Neuroanthropologist Terrence Deacon notes that 'an immense logical chasm appears to exist between explanations given in terms of telos and explanations given in terms of the familiar pushes and pulls of physics and chemistry. ${ }^{, 20}$ The debate regarding biological teleology is often reduced to two opposing extremes: either we eliminate teleology from the scientific image, or we give up and conclude that teleology is intrinsically mysterious and forever beyond human understanding. Deacon intends to go beyond these two views by proposing that teleology emerges naturally through the interaction of simple physical-chemical processes. He exemplifies this phenomenon with an autocell, a relatively simple molecular structure that is generated through the processes of autocatalytic cycle and a self-assembling capsule. The processes are mutually beneficial and it is the 'synergistic relationship between processes that reciprocally support one another's persistence. ${ }^{21}$ It is, Deacon suggests, the 'systemic interdependence, or synergy, and not any component molecules or chemical reactions that is the defining property of an autocell. ${ }^{22}$ But is this process an indication of purpose within the biological strata of reality? Deacon argues that the autocell demonstrates a view of teleology as produced by a process of co-dependence. That is, a 'self-organizing process that collectively and synergistically constituted an autonomous, self-maintaining, self-reconstituting unit: a self that benefits its own persistence ... ${ }^{23}$ We get spontaneous enddirectedness through self-organization, leading to the emergence of natural teleology.

A similar emphasis on self-organization is expressed by bio-complexity theorist Stuart Kauffman. Humanity and the whole of nature, according to Kauffman, are the products of the twin sources of order, namely selection and self-organization. ${ }^{24}$ Kauffman argues that the resistance to teleology is a by-product of a reductionist account of nature, a view of the natural order that goes back to Descartes, Galileo, and Newton. A mechanistic account of nature leaves no room for teleological principles, and we are left with the view that all of reality 'is nothing but whatever is "down there" at the current base of physics. ${ }^{25}$ Instead, he suggests that the biosphere continuously gives rise to unpredictable phenomena, new properties, and new entities with novel capacities and powers. The biosphere is creative in ways that escape current computational capacities, and the "physicist cannot simulate the evolution of the specific biosphere... ${ }^{26}$

This non-reductionist picture of the becoming of the natural world, through the workings of organizational laws, permits the existence of irreducible agency and teleology. Teleology is not an anomaly, but something which belongs to the fundamental level of nature. The goal, 
then, is to 'identify the minimum natural system to which it makes sense to attribute teleological explanations. ${ }^{27}$ Such a system should be able to, among other things, perform at least one work cycle, be individuated naturally, act on its own behalf and engage in selfpropagating work. This, argues Kauffman, can be seen in the behaviour of a bacterium; a bacterium swims up the glucose gradient 'to get' sugar. ${ }^{28}$ In this case, the bacterium is acting on its own behalf in its natural environment. Moreover, its behaviour entails teleological notions such as 'detecting', 'choosing', and 'acting'. A bacterium, however, is in fact quite complex, and we must ask if it is possible to deduce teleology from even simpler systems. Kauffman proposes here the idea of 'minimal molecular autonomous agents'. That is, very simple molecular systems which exhibit relative autonomy, engage in work cycles, reproduce, and have boundaries which allow for natural individuation. ${ }^{29}$ Based on the ontology of these molecular agents, we can say that teleology is a natural, yet irreducible, phenomenon. Moreover, it does not seem possible, according to Kauffman, to arrive at an adequate theory of how 'organismic processes self-organize' through 'pure physical description alone' ${ }^{30}$ This novel phenomenon of self-organization indicates the radical underdetermination of the biological by the physical, as well as the reality of teleological laws 'that could apply to life universally.' 31

Conway Morris challenges the randomness view of evolution, or what he calls the evolutionary orthodoxy, which claims that 'a creature is a contingent accident, assembled by chance histories and circumstances. ${ }^{32}$ He argues instead that there are 'preferred pathways' in evolution. Evolutionary convergence shows that we live in a constrained world. As he writes, convergence shows that 'at many levels evolution is seeded with probabilities, if not inevitabilities. ${ }^{33}$ There is a direction to evolution, and the appearance of human beings is not due to random occurrence. Indeed, humans are inevitable. Evolution is not random, but 'strongly selection-constrained along certain pathways and to certain destinations. ${ }^{34}$ The independent appearance of intelligence in evolutionary history, in organisms with markedly different biological makeup, seems to indicate teleology through convergence. The abundance of, in the biological world, 'striking examples of convergence underpins that such features may well be evolutionarily inevitable. . .' and that 'all intelligences could tend towards a similar end point., 35

Interestingly, Conway Morris does not merely suggest that the idea of convergence changes evolutionary science and our current conception of the biological world. He argues more 
strongly that evolutionary convergence carries metaphysical implications and that 'biology may be much closer to metaphysics than it often cares to acknowledge. ${ }^{36}$ The fact of convergence in evolution could suggest that it is a purposeful process, that evolutionary biology 'is the motor whereby the deeper realities of the universe may be uncovered..." ${ }^{37}$ Indeed, in the end of Life's Solution he argues that the phenomenon of convergence indicates that there are natural teleological laws at play in nature. In a similar way to Kauffman's laws of self-organization, Conway Morris seeks through the model of convergence to explain the seeming evolutionary directionality toward increasing complexity and emergence of conscious creatures. He even suggests that the tendency toward the emergence of life is itself a cosmic principle. In this way, Conway Morris clearly takes his analysis of evolution in a metaphysical direction that allows for theological interpretation and analysis. As he remarks, 'Not only is the Universe strangely fit to purpose, but so, too. . is life's ability to navigate its solutions.' $^{38}$

We must ask ourselves, given the phenomenon of convergence, if the evolutionary worldview is compatible with, and perhaps even entails, a theological account of nature as Creation? Convergence and immanent teleology, Conway Morris argues, does not presuppose, 'let alone proves, the existence of God, but all is congruent. 39

Next section will analyse further the possible congruency between Christian eschatology and natural teleology, and in what ways teleological laws allow for theological reflection regarding the eschatological fulfilment of a 'groaning' creation (Romans 8:22).

\section{NATURE AS CREATION: NATURAL TELEOLOGY IN LIGHT OF ESCHATOLOGY}

In what ways can an updated account of biological teleology aid in formulating and filling out the ontological content of an integrative and realist eschatology? ${ }^{40} \mathrm{~A}$ teleological account of biological processes, stressing the self-organizational, dynamic, and convergent dimension of the natural order, provides helpful resources for constructively explicating divine immanence and the role of the Spirit of bringing about the New Creation. Such display of immanent activity within the natural domain shows, moreover, that 'God's concerns are not limited to the human domain. Nothing less than the wider creation provides his palette. And the poured out Spirit is the brush that returns the color to the canvas. ${ }^{41}$ On Deacon's, Kauffman's, and Conway Morris's teleological accounts, the created order is continuously 
progressing towards greater complexity, giving credence to an ontology of creation beyond the 'nothing-buttery' of Gould, Rosenberg, and Weinberg. Indeed, by situating such teleology within an eschatological context we can more fully understand how the earthly connects with the heavenly as portrayed in Isaiah $32: 15-18$ and $44: 1-5^{42}$, and how an unfinished creation is anticipating the full indwelling of its Creator (1 Corinthians 15); an event which is proleptically promised in the resurrection of Jesus Christ. ${ }^{43}$ Furthermore, by ontologically grounding a form of directedness in the natural it becomes possible to shed light on God's creatio continua and the tranformatio mutandi, or renovatio, of physical reality; thus, holding together continuity and discontinuity of old and new creation. Such a vision of God's ongoing creative activity coheres well with a theistic understanding of evolution, as formulated by Howard Van Till: 'Drawing also from the vocabulary of the natural sciences, I envision a creation brought into being by God and gifted not only with a rich "potentiality space" of possible structures and forms, but also with the capacities for actualizing these potentialities by means of self-organization into nucleons, atoms, molecules, galaxies, nebulae, stars, planets, and the life-forms that inhabit at least one planet, perhaps more. ${ }^{44}$ However, one needs to be vary of fusing a teleological view of the Spirit's activity, and God's influence within evolutionary dynamics, with a naïve progressivism; the view that everything is progressively getting better. Creation is affected by sin. Death, pain, and sorrow came into this world through human disobedience and sinfulness. Hence, an eschatological engagement with teleology needs to be articulated in terms of cosmic renewal and redemption, and not reductive progressivism. ${ }^{45}$

Continuing on the topic of theistic evolution, a further reason for bridging natural teleology with eschatology is that it can aid in making ontological and epistemological sense of the 'biblical picture of the "humility of God.", 46 Whether God can be 'humble' is debated among scholars ${ }^{47}$, but God's incarnation in the Son and the Son's death on the cross seem to indicate self-giving and, perhaps, self-limitation on God's part. ${ }^{48}$ This theological theme has been explored by John Haught who argues that the messy world of Darwinian evolution is congruent with the kenotic "picture of an incarnate God who suffers along with creation. . .49 Theology, Haught argues, faces the important task to retrieve the image of a vulnerable God that refrains from interfering in the becoming of creation. It is here that it becomes relevant to think about creation's becoming in terms of natural teleological laws, because if we conceive ultimate reality 'fundamentally as self-emptying, suffering love, we should already anticipate that nature will give every appearance of being in some sense autonomously creative 
(autopoietic). ${ }^{50}$ Deacon's, Kauffman's and Conway Morris's post-reductionist ontologies, therefore, remain not only compatible with divine humility, but they provide important scientific insights regarding the ultimate structure of reality which may indicate something of the ontological consequences of God's humility.

\section{CHALLENGES FOR NATURAL TELEOLOGICAL ESCHATOLOGY}

A teleological conception of nature provides ample conceptual space for conceiving creation as a whole in eschatological terms. The natural world, it seems, is evolving toward greater complexity and increased interrelatedness among biological phenomena. However, despite the possibilities that such an updated teleology brings to theological construction, it should not lead to naive optimism. Indeed, construing eschatology through natural teleology can lead to theological tensions and invite philosophical problems, some of which I will explore further below. First, I will point out some general problems for construing eschatology in evolutionary teleological terms. Thereafter, I will focus on some theological and philosophical problems that seem to increase in strength, should one wish to take a teleological construal of eschatology in a non-interventionist direction.

Nicholas Adams notices the problems of uncritically transferring 'general' or 'secular' eschatologies into the domain of Christian theology. ${ }^{51}$ Adams shows through the eschatologies of Pannenberg, Moltmann and Rahner how secular forms of reasoning 'find their way not only into the peripheral language of Christian eschatology but often determine its very core. ${ }^{, 52}$ One source of tension is that the notion of 'time' acquires different meaning in secular eschatologies when compared to Christian eschatology. The former conceptualizes time without any reference to God; 'Christian eschatology, by contrast, means acknowledging that time is what God creates, redeems and sustains. ${ }^{53}$ Adams' motivation, it should be pointed out, "is not a variant of fundamentalism which seeks to isolate Christian speech from other kinds of discourse. ${ }^{54}$ Neither is it mine. Rather, it is a call for caution regarding the interdisciplinary project of synthesizing secular accounts of directedness and teleology with that of Christian eschatology. We should proceed in a cautionary manner, in a way that respects both secular sources of knowledge and the uniqueness and particularity of the Christian faith.

I will now turn to a few possible areas of tension and issues for further inquiry. How should we understand the relationship between evolutionary progress and the eschatological transformation of this creation? On an evolutionary teleology, the transformational aspects of 
nature are progressive, happening step by step. Biological history is crucial, and whatever happens is dependent on previous stages and phases of evolution. In many ways, the future emergence of biological phenomena is partly constrained by the total set of structural histories. In philosophy of emergence, scholars debate the relationship between two keyconcepts: supervenience and novelty. The anti-reductionist seeks to uphold two ontological assertions. On the one hand, emergent biological phenomenon $X$ must supervene on the physical, meaning that $X$ and $X$ 's causal powers are ontologically dependent on the base level from which it emerged. ${ }^{55}$ On the other hand, in order to retain the irreducible character of $X$, it must exhibit novel capacities or powers (something which cannot be reduced to any of $X$ 's constituent parts). It is debatable whether it is possible to hold these two ideas together, without one undermining the other; too much supervenience cancels out novelty and too much novelty breaks the relationship of dependency between the physical and emergent phenomena. ${ }^{56}$ This problem parallels, to some degree, the eschatological attempt at finding the correct balance between continuity and discontinuity of the old and new creation. It is contestable if evolutionary categories can lend sufficient ontological resources for framing the newness of the New Creation given that evolutionary becoming is dependent on previous biological structures. The future, on an evolutionary view, is very much ontologically constrained by the past. Hans Schwarz raises a similar point when he writes, 'Evolutionary concepts imply a continuous expansion and perhaps improvement of existing possibilities. Yet evolution allows for nothing genuinely new. We only encounter new arrangements of what we face now. The vision of a new world, however, goes beyond the possibilities and opts for something radically new. ${ }^{57}$ A potential problem could be that evolutionary continuity comes at the expense of discontinuity and the form of ontological novelty required for a robust theological account of the New Creation. ${ }^{58}$

Another area in need of further clarification pertains to the relationship between goals within nature and goals for nature. We see in the sketched three accounts of natural teleology how nature is construed in purposeful terms through self-organizational processes and convergent principles; how, as Deacon puts it, 'matter began to matter'. Goal-directedness can be seen as part and parcel of the natural order. However, on an eschatological reading of nature there are not just goals within nature. There is also an end-goal to nature's becoming, which is God's full indwelling in the New Creation. The consummation of creation, as portrayed in Revelation 21:3, means that 'It is no longer merely heaven that is named as the place where God dwells; heaven and earth are now to be newly created so that God himself dwell in them. 
. ${ }^{59}$ God will finally be all in all (1 Cor 15: 28). The eschata signifies not merely a transformative event within the boundaries of time, but it requires 'the consummation or at least transformation of the categories of time, space, and matter, or the world as we know it. ${ }^{60}$ It seems as if biology is silent on the issue of end-goals, and some consider the explanatory scope of the biological sciences as restricted to talking about proximate causes, not ultimate ones. ${ }^{61}$ Thus, when we talk about possible teleological aspects of nature, we need to conceptually clarify what kind of telos we are introducing into the discussion. This issue was raised by Ernst Mayr who wrote, 'for the evolutionary biologist there is a great difference between telos as goal and telos as endpoint. If one asks whether natural selection, and more broadly, all processes in evolution have a telos, one must be clear which telos one has in mind. ${ }^{62}$ The tricky issue, here, is how to extend a natural teleological framework, which focuses on biological trends and tendencies in nature, to the theological domain which emphasises the ultimate consummation of creation. Any successful synthesis of natural teleology with eschatology would have to concede the subordination of particular goals for individual biological phenomena to the overarching goal of the renovatio of creation. On this view, 'the ultimate biological end of any such organism would be subordinate, within a broader framework, to further ends of a different sort, having to do with the teleological process of evolution by natural selection, leading to the fulfilment of the divine goal. ${ }^{63}$ Indeed, 'the good' for biological organisms - whereby $S$ 's natural ends are intrinsically good for $S$ - would in some sense have to be subordinate to the goodness-maximization of the eschatological process as a whole. ${ }^{64}$

At this point, another issue emerges. If it is the case that teleological phenomena are made physically manifest because of God's providential plan for creation, then does this not rule out intrinsic teleology? Intrinsic teleology, following Simon Oliver, 'refers to a goalorientated behaviour which belongs to something by virtue of what it is. ${ }^{95}$ Human artefacts, however, such as cars or vacuum cleaners, while they exhibit some form of end-directedness, owe their teleology to an outside source. Extrinsic teleology, therefore, 'refers to an entity which is essentially inert or passive and which has teleological orientation imposed from without. ${ }^{66}$ The danger is that an extrinsically grounded teleology in the eschatological intention of God would render biological teleology epiphenomenal. ${ }^{67}$ To put it directly, God would be doing all the causal labour. This sort of teleology would turn into Mayr's teleonomy. I believe this tension to be real but not unsolvable. 
It is helpful here to consider Moltmann's pneumatological articulation of God's ongoing presence in creation based on Yahweh's ruach (Gen 1:2, Ps 33:6, Eccles 12:7; 3:21). As Moltmann explains, when ruach is mentioned 'a distinction is often made between God's own creative power to give life, and the created ability to live enjoyed by all the living. ${ }^{68}$ Drawing together Yahweh's ruach (breath) and dabar (word), Moltmann further suggests that 'If this unity of breath and voice is carried over to God's creative activity, then all things are called to life through God's Spirit and his Word. ${ }^{69}$ Moltmann's distinction is very important and helpful, as God can be seen as the ontological foundation of a 'created ability', without overriding the teleological striving of biological organisms. Such a distinction is possible, because while we maintain that God is actively present in all things, 'this does not mean making God the same as everything else. ${ }^{70}$ While God's ruach, as manifested in intrinsic and efficacious teleological behaviour, has a 'transcendent origin', the 'power to live enjoyed by everything that is alive is its immanent side. ${ }^{, 71}$ Thus, as I argued above, biological teleology provides resources for framing divine immanence. It seems fully possible to hold together extrinsic and intrinsic teleology, without the former cancelling out the latter. Moreover, in holding together intrinsic and extrinsic teleology one can bypass the conclusion that an affirmation of biological teleology amounts to a design-argument for the existence of God. Alister McGrath explains this nicely, 'Teleology must be distinguished from design, despite the frequent conflation in popular writings. Design is to be understood as conscious intent and artifice applied externally to the order of nature, in order to achieve some end or external goal. . . ${ }^{72}$ Conversely, teleology indicates an intrinsic aspect of biological organisms.

This paper will now proceed with a final discussion. The reality of biological teleology can properly be construed as a consequence of God's eschatological presence and activity. Finding ways of linking up natural phenomena and occurrences to divine intentionality is nothing new but have preoccupied and still preoccupies a number of theologians and philosophers. One such area is the so called 'divine action project' (DAP) ${ }^{73}$, and within it the number of science-religion scholars that have devised strategies for accounting for God's action in a non-interventionist manner. I want to sketch a couple of reasons for why a) my proposal is not a non-interventionist contribution to DAP, and how b) a robust eschatology significantly shapes and challenges some presuppositions within DAP.

Those who endorse a non-interventionist route for the God-World relationship typically make the following kind of statements: 'The processes revealed by the sciences are in themselves 
God acting as creator, and God is not to be found as some kind of additional influence or factor added on to the processes of the world God is creating, 74 , 'natural processes in the world be regarded as such as God's creative action'75, 'the world's most fundamental causal principles are never interrupted" ${ }^{76}$, implying that "there would be no qualitative or ontological difference between the regularity of natural law conceived as expressing the regular or repetitive operation of divine agency and the intentionality of special divine actions. ${ }^{, 77}$ These statements entail that whatever God brings about in reality is done solely through natural processes, and there is no ontological distinction to be made between divine intention and physical causation. To differentiate between the two (according to these scholars) is to open wide the door for a problematic dualism and supernatural causation. This means that God, in order to achieve a certain outcome, has to exert influence from outside of creation, hence suspending or breaking natural laws. The ambition of DAP is to hold together God's transcendence and immanence by negating the ontological difference between God's actions and the physical processes studied by natural science. I would suggest, in contrast to the many supporters of DAP, that such a non-interventionism runs into a severe causal problem. First of all, if one completely collapses the distinction between divine intentionality, call it $G$, and physical causation or processes, call this $P$, then God-talk becomes superfluous. That is, if an explanation of an effect $E$ through $G$ is identical to $P$, then there is no longer any reason to interpret $E$ as instance of divine action, $G .^{78}$ Based on epistemic simplicity, one could argue that $G$ should be left out. ${ }^{79} P$ (causal processes that science describes) alone could be seen as sufficient. Secondly, and this is connected to the first point, the idea of attributing two causes for one single event amounts to philosophical incoherence. This point has been carefully articulated by philosopher Jaegwon Kim through the 'causal exclusion principle/argument'. I will provide a quite lengthy quote so as to highlight the conundrum of positing two causes for one event.

'First, suppose that we trace the causal chain back from my bodily motion - to simplify, the movement of my left foot as I take my first step toward the kitchen. I assume we have a pretty good neurophysiological story to tell about how such limb motion occurs, a story involving transmission of neural signals, contraction of a group of muscles, and so on; let us suppose that the story ends with some neural event in my central nervous system, presumably the firing of a group of neural fibers somewhere deep in my brain. There seems every reason to think that such a neurophysiological causal explanation also exists; at least, we cannot rule out such a possibility. What then is the relationship between this explanation and the intentional explanation in terms of my belief and desire? One invokes a neural state, $N$, as a cause of my foot movement; the other invokes my desire for a drink of water, as a cause of the very same event. How are these two causes related to each other? ${ }^{80}$ 
The problem, as Kim goes on to argue, is that by stating the presence of two causal stories for $E$, each claiming to offer a complete account of $E$, one creates an unstable situation which demands an explanation for how it is that the origin of $E$ is to be accounted for in terms of two different causes. ${ }^{81}$ Similarly for the type of non-interventionism now discussed, one needs to demonstrate how it is that $G$ and $P$ both account for a single explanandum, without $P$ undermining $G$ or vice versa.

The non-interventionist project of minimizing or completely rejecting any ontological difference between God's active presence and physical causation leads, therefore, to troubling implications for our causal picture. Thus, I want to suggest that while God's eschatological transformation can be seen as mediated through biological teleology, there remains a qualitative difference between such teleological processes and divine influence. But, doesn't this ontological distinction lead to a problematic picture of God exerting external influence and thereby upsetting the harmony of physical reality? Our non-interventionist friends certainly think it does.

What kind of assumptions give rise to this problem, and what view of nature is it that creates the demand for non-interventionist solutions? ${ }^{82}$ One common assumption within DAP is that the universe is a causally closed system. Hence, if God acts externally with regard to the physical then the laws of nature will have to give. In a way, God stands in competition to the universe. Such a causal closure principle is usually defined in the following ways: 'every event has a sufficient physical cause', 'if you trace back an event to its cause you never have to leave the physical domain', 'If a physical event has a cause at $t$, then it has a physical cause at $t{ }^{, 83}$ Needless to say, the causal closure principle comes in many forms and while its general claim is easy to understand, it is rather difficult to find a sufficient definition for it. ${ }^{84}$

Not only is it very difficult to define the thesis of causal closure, but from a Christian standpoint such a metaphysical principle seems unjustifiable and question-begging. ${ }^{85}$ This is not to adopt fideism, as Lydia Jaeger points out. It is simply to stress the basic theological conviction of God as creator: 'If God is the Creator of the universe, his action in it is not a problem to be figured out, but a reality to be acknowledged and the very foundation of whatever we can say about the world. ${ }^{96}$ Jaeger, thus, poses a theological challenge to a coreassumption (which led to the idea of nature resisting divine influence) within DAP.

An eschatological appreciation of nature dissolves the dichotomy between God and World, and bypasses the causal-closure principle that has necessitated non-interventionist theologies. 
Nature, viewed in light of eschatology and the redemptive history of humanity and cosmos, is not a 'closed system, perfect in itself and totally self-sufficient. ${ }^{87}$ The notion of God bringing about a new creation indicates strongly that God is not excluded from or limited by the processes and structures of this world. I would further argue that an eschatological understanding of nature makes biological teleology plausible, and far from an ontological anomaly to be explained away in terms of mechanistic causation. Moreover, the Parousia (Matthew 24:3, 27, 37, 39; 1 Thessalonians 4:13-5.11; 1 Corinthians 15:23, 2 Peter 3:10-13), indicates nature as an ongoing process that will transition into a new creation. As David Wilkinson notes, 'the Parousia is a reminder that the world is not a closed system. ${ }^{88}$ Creation is profoundly teleological and points to a future where 'there shall be no more death, neither sorrow, nor crying, neither shall there be any more pain: for the former things are passed away' (Revelation 21:4).

\section{CONCLUSION}

This paper has evaluated the promises and challenges of framing Christian eschatology through natural (biological) teleology. It has been noted that a constructive engagement with teleology carries benefits for our understanding of the role of the Spirit in the coming of the New Creation, theistic evolution, and also for the notion of God's humility. Nevertheless, it remains to be seen if natural teleology, evolutionarily construed, can lend sufficient ontological resources for upholding the idea of a New Creation. It was also argued that more work needs to be done on the issue of bridging teleological goals within nature and the eschatological end-goal for physical reality as a whole. I suggested that the attempt to synthesise eschatology and natural teleology should not be construed as a form of noninterventionism, but that an eschatological account of creation challenges non-interventionist assumptions regarding God's action.

\footnotetext{
${ }^{1}$ I am aware that eschatology is one of the more controversial theological doctrines, with numerous interpretations of what will happen at the end of time, or what it means for God to bring creation to fulfilment (millennialism, premillenialism, futurism, dispensationalism, etc.). Throughout this paper, I take a broad approach to eschatology, assuming only that God will bring about a New Creation with a level of continuity and discontinuity at some point and in some way.

2 John F. Haught, Deeper than Darwin: The Prospect for Religion in the Age of Evolution (Cambridge, MA: Westview Press, 2003), p. 186.

${ }^{3}$ Michael Ruse, 'Teleology in Biology: Is it a Cause for Concern?', Trends in Ecology and Evolution 4 (1989), pp. 51-54.

${ }^{4}$ Steven Weinberg, Dreams of a Final Theory (New York: Vintage Books, 1993), p. 255.
} 
${ }^{5}$ William Provine, 'Progress in Evolution and Meaning in Life,' in Mathew H. Nintecki (eds.), Evolutionary Progress (Chicago and London: University of Chicago Press, 1988), p. 64.

${ }^{6}$ Stephen Jay Gould, 'On replacing the idea of progress with an operational notion of directionality,' in Matthew H. Nitecki (ed), Evolutionary Progress (Chicago: University of Chicago Press, 1988), p. 319.

${ }^{7}$ Alex Rosenberg, The Atheist's Guide to Reality: Enjoying Life Without Illusions (New York and London: W. W. Norton \& Company, 2011), p. 43.

${ }^{8}$ Teleology is linked up to purposeful behaviour: 'The term purposeful is meant to denote that the act or behavior may be interpreted as directed to the attainment of a goal-i.e., to a final condition in which the behaving object reaches a definite correlation in time or in space with respect to another object or event. Purposeless behavior then is that which is not interpreted as directed to a goal.' Arturo Rosenblueth, Norbert Wiener and Julia Bigelow, 'Behavior, Purpose and Teleology', Philosophy of Science 10 (1943), p. 18.

${ }^{9}$ Richard Cameron, 'Aristotle's Teleology', Philosophy Compass 5 (2010), p. 1096.

${ }^{10}$ Michael Ruse, 'Evolutionary biology and the question of teleology', Studies in History and Philosophy of Biological and Biomedical Sciences 58 (2016), p. 101.

${ }^{11}$ Woodfield writes: 'The most common criticisms of teleological explanations nowadays are either that they are animistic, i.e. they assume that the thing in being explained has a mind, or that they tacitly invoke a supernatural being who directs the course of events.' Andrew Woodfield, Teleology (London and New York: Cambridge University Press, 1976), p. 3.

${ }^{12}$ Cameron, 'Aristotle's teleology', p. 1097.

13 Ibid.

${ }^{14}$ Michael Chase, 'Teleology and Final Causation in Aristotle and in Contemporary Science', Dialogue 50 (2011), p. 513.

${ }^{15}$ Ibid.

${ }^{16}$ Cameron, 'Aristotle's teleology', p. 1100.

17 Ibid., p. 1096.

${ }^{18}$ Denis M. Walsh, 'Mechanism and Purpose: A case for natural teleology', Studies in History and Philosophy of Biological and Biomedical Sciences 43 (2012), p.174.

${ }^{19}$ Michael Ruse, Taking Darwin Seriously: A Naturalistic Approach to Philosophy (New York: Prometheus Books, 1998), p.17.

20 Jeremy Sherman and Terrence W. Deacon, 'Teleology for the Perplexed: How Matter Began to Matter', Zygon: Journal of Religion and Science 42 (2007), p.874

21 lbid., p.887.

22 Ibid., p.888.

${ }^{23}$ Ibid., p. 896.

${ }^{24}$ Stuart Kauffman, At Home in the Universe: The Search for the Laws of Self-Organization and Complexity (New York: Oxford University Press, 1995), p. 71.

${ }^{25}$ Stuart Kauffman, Reinventing the Sacred: A New View of Science, Reason, and Religion (New York: Basic Books, 2008), p. 11.

26 Ibid., 39.

27 Stuart Kauffman and Philip Clayton, 'On emergence, agency, and organization', Biology and Philosophy 21 (2006), p. 505.

${ }^{28}$ Kauffman, Reinventing the Sacred, p. 78.

${ }^{29}$ Stuart Kauffman, Investigations (New York: Oxford University Press, 2000), pp. 53-73; Kauffman and Clayton, 'emergence, agency, organization', pp. 505-511.

${ }^{30}$ Kauffman and Clayton, 'emergence, agency, organization', p. 511.

${ }^{31}$ Ibid.; Kauffman, Reinventing the Sacred: A New View of Science, p. 59.

${ }^{32}$ Simon Conway Morris, Life's Solution: Inevitable Humans in a Lonely Universe (Cambridge and New York: Cambridge University Press, 2003), p. 284.

33 Ibid., p. 298.

${ }^{34}$ Ruse, 'Evolutionary biology and the question of teleology', p. 104.

${ }^{35}$ Simon Conway Morris, 'Evolution and Convergence: Some Wider Considerations,' in Simon Conway Morris (ed.) The Deep Structure of Biology: Is Convergence Sufficiently Ubiquitous to Give a Directional Sign (West Conshohocken, PA: Templeton Press, 2008), p. 58.

${ }^{36}$ Ibid., p. 61.

37 Ibid., p. 62. 
${ }^{38}$ Simon Conway Morris, Life's Solution: Inevitable Humans in a Lonely Universe (Cambridge and New York: Cambridge University Press, 2003), p. 327.

39 Ibid., p.330.

${ }^{40}$ By a realist eschatology I mean the following: 'eschatological realities have to stand in both discontinuity and continuity to realms and forms of experience related to material nature, if they are supposed to make sense to the natural and cultural sciences and if they want to stay attuned to important strata of the biblical witnesses.' Michael Welker, 'Realistic Eschatology' in John Polkinghorne and Michael Welker (eds.), The End of the World and the Ends of God: Science and Theology on Eschatology (Harrisburg, PA: Trinity Press International, 2000), p. 205.

${ }^{41}$ Graham A. Cole, He Who Gives Life: The Doctrine of the Holy Spirit (Wheaton, Illinois: Crossway Books, 2007), p. 141.

42 Michael Welker, God the Spirit, trans. John F. Hoffmeyer (Minneapolis: Fortress Press, 1994), pp. 142-144.

${ }^{43}$ See Jürgen Moltmann, Science and Wisdom, trans. Margaret Kohl (Minneapolis: Fortress Press, 2003), pp. 44-47.

${ }^{44}$ Howard Van Till, 'The Fully Gifted Creation' in J.P. Moreland and John Mark Reynolds (eds.) Three Views on Creation and Evolution (Grand Rapids, Michigan: Zondervan, 1999), p. 203.

45 J. Richard Middleton, A New Heaven and a New Earth: Reclaiming Biblical Eschatology (Grand Rapids, MI: Baker Academic, 2014), pp. 155-175.

46 John F. Haught, God After Darwin: A Theology of Evolution (Philadelphia: Westview Press, 2008), p. 51.

${ }^{47}$ For a critique of the idea of divine humility, see Daniel A. Campana, 'On the "Vanity of God": A Reply to Taliaferro', Faith and Philosophy 9 (1992), pp. 105-108. For an excellent overview regarding the notion of humility in Christian theology see, Stephen T. Pardue, The Mind of Christ: Humility and the Intellect in Early Christian Theology (New York and London: Bloomsbury T\&T Clark, 2013).

${ }^{48} \mathrm{C}$. Stephen Evans provides insightful arguments for the possibility of God's self-limitation: C. Stephen Evans, 'Kenotic Theology and the Nature of God' in C. Stephen Evans (ed.) Exploring Kenotic Christology: The SelfEmptying God (Oxford: Oxford University Press, 2006), pp. 190-217.

${ }^{49}$ Haught, God after Darwin, p. 54.

50 Ibid., p. 57.

${ }^{51}$ Nicholas Adams, 'Eschatology Sacred and Profane: The Effects of Philosophy on Theology in Pannenberg, Rahner and Moltmann', International Journal of Systematic Theology 2 (2000), pp. 283-306. See also Adams, 'The Present Made Future: Karl Rahner's Eschatological Debt to Heidegger' Faith and Philosophy 17 (2000), pp. 191-211.

52 Ibid., p. 286.

53 Ibid.

${ }^{54}$ Ibid.

${ }^{55}$ Alex Rosenberg and Daniel W. McShea, Philosophy of Biology: A Contemporary Introduction (New York and London: Routledge, 2008), pp. 114-119.

${ }^{56}$ For a critique of combining of supervenience and emergent novelty, see Jaegwon Kim, 'Making Sense of Emergence', Philosophical Studies 95 (1999), pp. 3-36; Kim, 'Emergence: Core Ideas and Issues', Synthese 151 (2006), pp. 547-559; Kim, 'The Myth of Nonreductive Materialism', Proceedings and Addresses of the American Philosophical Association 63 (1989), pp. 31-47. See also my, 'From Emergence to Panpsychism: A Critical Evaluation of Nancey Murphy's Non-reductive Physicalism', Sophia: International Journal for Philosophy and Traditions 55 (2016), pp. 381-394.

${ }^{57}$ Hans Schwarz, Eschatology (Grand Rapids, MI, and Cambridge, UK: WM. B. Eeerdmans Publishing Co., 2000), p. 387.

58 Newness is a debated topic among emergence and complexity theorists, and some theories are stronger than others when it comes to the question of whether emergence implies the introduction of new entities or not. A very strong form of emergence would not only a) 'individuate relational complexes', b) 'ascribe reality to them through an ontology of relations', c) say that $X$ is emergent in virtue of new causal powers, but also claim d) that the emergence of $X$ constitutes a new substance. See 'Conceptual Foundations of Emergence Theory' in Philip Clayton and Paul Davies (eds.), The Re-Emergence of Emergence (New York: Oxford University Press, 2006), p. 14.

${ }^{59}$ Moltmann, Science and Wisdom, p. 45.

${ }^{60}$ Schwarz, Eschatology, p. 387. For a discussion regarding time, eternity, and the eschaton, see Markus Mühling, T\&T Handbook of Christian Eschatology, translated by Jennifer Adams Maßman and David Andrew Gilland (London and New York: Bloomsbury T\&T Clark, 2015), pp. 80-132. 
${ }^{61}$ Ernst Mayr, 'Cause and Effect in Biology,' in Michael Ruse (eds.), The Philosophy of Biology, $2^{\text {nd }}$ edition (New York: Prometheus Books, 2007), pp. 49-62.

${ }^{62}$ Ernst Mayr, 'The Idea of Teleology', Journal of the History of Ideas 53 (1992), p. 123.

${ }^{63}$ William J. FitzPatrick, Teleology and the Norms of Nature (New York and London: Garland Publishing, Inc., 2000), p. 183

${ }^{64}$ Woodfield's account of organic functions links up with goods for specific organisms: 'S's bodily functions do S good by promoting S's natural ends, where "ends" means states or processes or activities that are intrinsically good for S.' Woodfield, Teleology, p. 130.

${ }^{65}$ Simon Oliver, 'Teleology Revived? Cooperation and the Ends of Nature', Studies in Christian Ethics 26 (2013), p. 159.

${ }^{66}$ Ibid., 160. Jonathan Jacobs makes a similar distinction to that of Simon Oliver between intrinsic teleology and conferred teleology. See Jonathan Jacobs, 'Teleology and Reduction in Biology', Biology and Philosophy 1 (1986), pp. 389-399.

${ }^{67}$ Interestingly, Ted Peters and Martinez Hewlett opt for an extrinsic and theistic conception of teleology by arguing that 'nature's purpose is not inherent within nature itself. . . its value or direction belongs to the relationship of nature with God.' See Ted Peters and Martinez Hewlett, Evolution from Creation to New Creation: Conflict, Conversation, and Convergence (Nashville, Abingdon Press, 2003), p. 49.

68 Jürgen Moltmann, The Spirit of Life: A Universal Affirmation, translated by Margaret Kohl (London: SCM Press Ltd, 1992), p. 41.

69 Ibid.

70 lbid., p. 42.

${ }^{71}$ Ibid.

${ }^{72}$ Alister McGrath, Darwinism and Divine: Evolutionary Thought and Natural Theology (West Sussex: WileyBlackwell, 2011), p. 189.

${ }^{73}$ For an excellent overview and summary of this (still ongoing) project, see Wesley Wildman, 'The Divine Action Project, 1988-2003', Theology and Science 2 (2004), pp. 31-75.

${ }^{74}$ Arthur Peacocke, 'Articulating God's Presence in and to the World Unveiled by the Sciences,' in Philip Clayton and Arthur Peacocke (eds.), In Whom We Live and Move and Have Our Being: Panentheistic Reflections on God's Presence in a Scientific World (Grand Rapids, MI and Cambridge, UK: William B. Eeerdmans Publishing Company, 2004), p. 144.

75 Ibid., p. 145.

${ }^{76}$ David Ray Griffin, Reenchantment without Supernaturalism: A Process Philosophy of Religion (Ithaca, NY and London, UK: Cornell University Press, 2001), p. 44.

77 Philip Clayton, 'Panentheism in Metaphysical and Scientific Perspective,' in Clayton and Peacocke (eds.), p. 84.

${ }^{78}$ Philip Clayton seems to be aware of this problem when he writes, 'One treads a delicate line here. The more vague the allusions to divine influences on the world, and the more they are based on a pure appeal to mystery, the less convincing they become for those who are sceptical in principle about the reasonableness of claims for divine action. Conversely, the more compatible such claims turn out to be with acceptable natural accounts of human agency, the more credible they become. Yet if the resulting account is identical to the natural accounts in everything it predicts, there is no reason to interpret it as an instance of divine action.' Philip Clayton, Mind and Emergence: From Quantum to Consciousness (Oxford and New York: Oxford University Press, 2004), p. 193.

${ }^{79}$ This argument is applicable generally to panentheistic conceptions of divine action. See my article, 'Is Panentheism Naturalistic? How Panentheistic Conceptions of Divine Action Imply Dualism', Forum Philosophicum: International Journal for Philosophy 19 (2015), pp. 209-225. James H. Fetzer makes a similar argument in relation to David Ray Griffin's process theology. James H. Fetzer, 'Evolution and Atheism: Has Griffin reconciled science and religion?', Synthese 178 (2011), pp. 394-395.

80 Jaegwon Kim, Mind in a Physical World: An Essay on the Mind-Body Problem and Mental Causation (Cambridge, MA: The MIT Press, 1998), p. 64.

${ }^{81} \mathrm{Kim}$ evaluates some alternative explanations for how a single event can have two causes. Alternative explanations include: a) each cause sufficiently explains $E$, so $E$ is overdetermined, b) the two causes jointly account for $E, c$ ) one cause is a part of the other, $d$ ) the two causes are ontologically identical, but semantically distinctive. Kim concludes that such options are 'nonstarters' and introduce more problems than they solve. Kim, Mind in Physical World, pp. 64-65. 
82 Interventionism could, of course, be objected to on theological rather than scientific, grounds. See, for example, David Ray Griffin, Evil Revisited: Responses and Reconsiderations (New York: State University of New York Press, 1991), pp. 14-21.

${ }^{83}$ Jaegwon Kim, Physicalism or Something Near Enough (Princeton and Oxford: Princeton University Press, 2005), p. 15.

${ }^{84}$ It is in fact, as E.J. Lowe argues, 'very difficult, if not impossible, for the physicalist to formulate a causal closure principle which is neither too strong nor too weak...' E.J. Lowe, 'Causal Closure Principles and Emergentism', Philosophy 75 (2000), p. 573.

${ }^{85}$ As Alvin Plantinga suggests, theological and philosophical investigations must proceed on the basis of the totality of the Christian evidence-base, which includes 'theism, belief in God and also the main lines of the Christian faith. . ' Alvin Plantinga, Where the Conflict Really Lies: Science, Religion, and Naturalism (Oxford and New York: Oxford University Press, 2011), p. 168.

${ }^{86}$ Lydia Jaeger, 'Against Physicalism-Plus-God: How Creation Accounts for Divine Action in Nature's World', Faith and Philosophy 29 (2012), p. 304.

${ }^{87}$ Moltmann, Science and Wisdom, p. 36.

${ }^{88}$ David Wilkinson, Christian Eschatology and the Physical Universe (London: Bloomsbury Academic, 2010), p. 68. 